\title{
Aeromania and Enlightenment: The Politics of Hot Air Balloons in Karamzin's "Letters of a Russian Traveler"
}

\author{
Rodolphe Baudin \\ Sorbonne University \\ Rodolphe.baudin@sorbonne-universite.fr
}

\begin{abstract}
:
This paper focuses on Karamzin's depiction, in Letters of a Russian Traveler, of Abbé Miolan's failed hot air balloon flight in Paris in July 1784. After briefly tracing the history of aeromania in late eighteenth-century France and England, as well as its contemporary Russian reception, notably by Catherine the Great, the paper identifies Karamzin's sources of information on the event and analyses the reasons why the Russian writer mentioned it in his travelogue. It demonstrates that Karamzin's depiction of a physical experiment embodying European capacity for innovation in the late eighteenth century was not an expression of scientific curiosity. Instead, the young writer used the episode as a metaphor of social and political management, in order to reflect on the questions of social autonomy and the relation of the enlightened public with State power in both France and Russia. By depicting Miolan's failed flight as a condemnable nuissance to public order, reminiscent of the revolutionary trouble he had witnessed during his journey through France, Karamzin showed his endorsement of Catherine's conservative conception of the Enlightenment. By depicting how the French public sphere dealt with Miolan and possibly implicitly comparing it with the way Catherine had dealt with Radishchev, he nevertheless showed the superiority of self-regulation over political violence in managing the nobility's growing longing for autonomy.
\end{abstract}

Keywords:

Karamzin, Letters of a Russian Traveler, travelogue, aeromania, Miolan, Catherine the Great, political management, social order, public sphere, autonomy of the nobility, relation to State power.

\section{Introduction}

A "sentimentalist Bible"2 for its first readers, Nikolai Karamzin's "Letters of a Russian traveler" was also a source of information on Western innovation, and as such an important tool of cultural transfer and intellectual modernization in Russia. Were the "Letters," however, a vehicle for technology transfers as well? In order to address this question, this study will focus on how Karamzin, as a Russian nobleman traveling abroad, reflected on aeromania, a new phenomenon, closely linked with the concept of innovation and the cultural mechanisms of technology transfers.

In order to do so, this study will first briefly recall the history of aeromania in France and Britain in the 1780 s, then its contemporary reception in Russia, before focusing on a brief episode in "Letters of a Russian Traveler" involving two anecdotes on the pitiful

\footnotetext{
${ }^{1}$ This paper was originally presented as a talk at the "Constructing Europe: Social and Cultural Transfer from the Atlantic to the Urals" Conference at the Federal University of Ekaterinburg on November 15-19, 2017. I thank Andrei Zorin and Andreas Schönle, as well as my two anonymous reviewers, for their reading of my text and their insightful comments.

${ }^{2}$ A. G. Cross, N. M. Karamzin. A Study of his Literary Career 1783-1803 (Carbondale and Edwardsville: Southern Illinois University Press, 1971), 66.
} 
adventures of Abbé Miolan, a lecturer in physics, who became famous in 1784 for undertaking an unsuccessful flight attempt in the Luxembourg Garden in Paris.

As this study will demonstrate, Karamzin's narrative about Miolan's misadventure excluded any reflection on aerostation as a branch of science or new technology, in order to turn it into a metaphor about social modernity. As such, it also carried out a political message, which turned out to be part of the transfer of ideas programmed by "Letters of a Russian Traveler".

\section{Aeromania in the 1780 s and its Reception in Russia}

Aeromania, or balloonomania as a topic of social and cultural history has attracted the growing attention of scholars in recent decades. Major studies include Richard Gillespie's pathbreaking piece on aerostation in France and Britain from 1783 to $1786 .{ }^{3}$ Gillespie explains that while aerostation was considered seriously in France from its very birth, it was not so in Britain, where it immediately became an element of show business, because of the lack of interest shown by the institutional intellectuals of the British scientific elite. Whereas in France, the existence of a solid network of scientific institutions, including provincial ones, was active in supporting innovation, even coming from simple craftsmen, and passing it on to centralized Parisian institutions, which would create specific committees to investigate and finance it, Britain's exclusive focus on abstract sciences, mainly mathematics, and the indifference towards air balloons shown by Sir Joseph Banks-president of the Royal Society of London and titular head of British science-led to abandoning aerostation in the hands of show runners, eager to make money out of the public's general interest for this new phenomenon. In other words, whereas in France aerostation quickly became an elite science, in Britain it remained a popular attraction for the crowds. ${ }^{4}$

This social differentiation is at the centre of Paul Keen's paper on the interactions between science and spectacle in 178 os England. ${ }^{5}$ After pointing out the general interest of the British public for this new trend, Keen highlights different anxieties triggered in contemporary commentators by aerostation. The first and foremost had to do with the fact that balloon flights attracted a mixed crowd, reaching far beyond the polite gentry. ${ }^{6}$ Besides this disturbing issue of potentially blurred social barriers, Keen points out other causes of anxiety. According to this scholar, balloons could be seen as a sign of either progress or decline, whether they were considered as a scientific achievement, or as a mere childish attraction. ${ }^{7}$ This ambivalence was all the more disturbing as the general

\footnotetext{
${ }^{3}$ R. Gillespie, "Ballooning in France and Britain, 1783-1786. Aerostation and Adventurism," ISIS, 75 (1984): 249-68. More recent studies include D. Arecco, Montgolfiere, scienze e lumi nel tardo Settecento: Cultura accademica e conoscenze tecniche dalla vigilia della Rivoluzione francese all'età napoleonica (Bari: Cacucci, 2003) and M. R. Lynn, The Sublime Invention: Ballooning in Europe, 1783-1820 (London: Pickering and Chatto, 2010).

${ }^{4}$ Gillespie's opinion is somewhat nuanced by Belhoste, who writes that in France, aeromania also eventually became a part of show business. See B. Belhoste, Paris savant. Parcours et rencontre au temps des Lumières (Paris: Armand Colin, 2011), 145.

${ }^{5}$ P. Keen, “The 'Balloonomania': Science and Spectacle in 1780s England," Eighteenth-Century Studies, 39, no. 4 (2006), 507-35. On British "balloonomania," see also L. Aliab'eva, "Vozdushnyi shar kak razvlechenie: iz istorii angliskoi vozdukhoplavatel'noi likhoradki," Novoe Literaturnoe Obozrenie, 76 (2005), 101-125.

${ }^{6}$ Keen, 522, 524.

${ }^{7}$ Keen, 525. According to Gillespie, Joseph Banks criticized the "vanity and childishness" of the aeronauts. See Gillespie, 265.
} 
interest for aerostation was considered as a mirror of the state of the country as a whole and of the state of British collective identity. ${ }^{8}$ Was this identity, so anxiously staged in the brutish yet prosperous John Bull, affirming its masculinity in this new triumph of science and human boldness? Or was it facing the risk of effeminacy under the influence of a trend, launched by France, and whose success triggered the production of countless byproducts in the fields of fashion and decorative arts? ${ }^{9}$ (Figure 1)

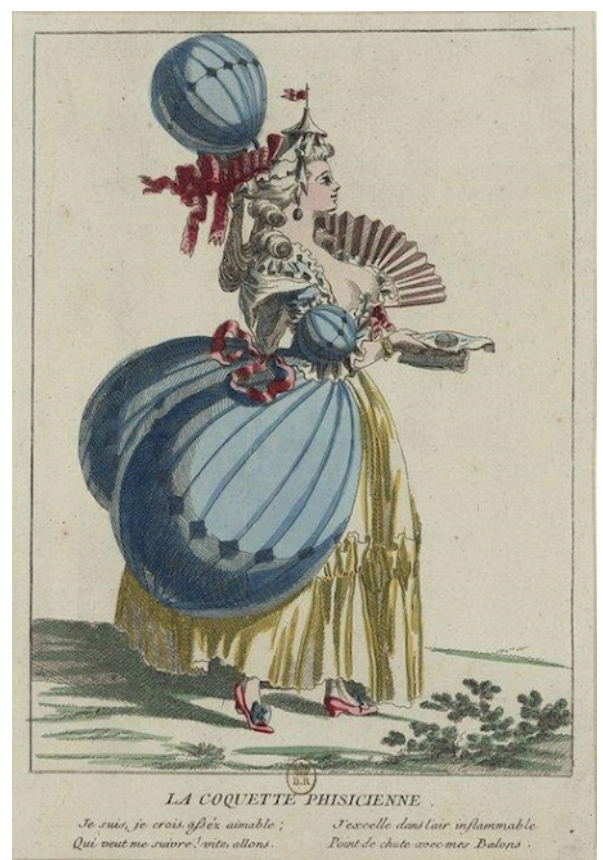

Fig. 1: La coquette phisicienne, 1784, Anonymous colored engraving (c) Gallica, BNF)

This last aspect reveals the role played by xenophobia in the British rejection of hot air balloons. This xenophobia, which appears in many comments made by contemporaries regarding the national origin of the new invention or the nationality of the various aeronauts who put up public flights in Britain, ${ }^{10}$ was also present in Russia.

Indeed, as John T. Alexander has shown, aeromania was not alien to Catherine's Russia. ${ }^{11}$ Scientists discussed it in the Academy of Sciences and the Imperial Surgical

\footnotetext{
${ }^{8}$ Keen, 524 .

${ }^{9}$ Keen, 518, 520, 525 .

${ }^{10}$ The most famous aeronaut in 178 os England was an Italian, Lunardi, who, as Keen shows, became the object of sexual innuendos in contemporary satire. He was also associated with France, the country which launched aeromania, and which shared Italy's feminine collective identity in the eyes of the British. On this, see Keen, 529-30.

"I. T. Alexander, “Aeromania, 'Fire-Balloons,' and Catherine the Great's Ban of 1784," The Historian, 58 (1996): 497-516. More recently, Russian aeromania was investigated in R. Collis, "'A Veritable Eldorado': European Wondermongers in Russia, 1755-1803," in ed. E. Waegemans, H. van Konigsbrugge, M. Levitt and M. Ljustrov, A Century Mad and Wise: Russia in the Age of the Enlightenment, (Groningen: Netherlands Russia Centre, 2015), 489-517. In the last section of his paper, Collis focuses on aeromania and its use by conjurors in early nineteenth-century Russia. For another recent study of aeromania during the reign of Alexander I, see T. Smoliarova, "Vzlet kak vzgliad, ili Bel'giets v russkom nebe", Novoe literaturnoe obozrenie, 76 (2005): 45-65. In her study, Smoliarova focuses on the flights put up by the Belgian adventurer Robertson in Russia in 1804-06 and their reception in contemporary Russian culture, while connecting aerostation with the evolution of ways of visually framing reality in the early nineteenth century.
} 
School, as well as at the University of Moscow. ${ }^{12}$ Russian journals, starting with the Moskovskie vedomosti, reported extensively on foreign flights, mainly by reproducing reports published in various European journals. ${ }^{13}$ But balloons were also a topic addressed several times by Catherine and Grimm in their correspondence. ${ }^{14}$ Finally, two flight attempts were organized in Moscow in February-March 1784, the first of which was described by Andrei Bolotov in his memoirs, whereas the second became the matter of a report in the Moskovskie vedomosti. ${ }^{15}$

The reason why this general interest did not result in any boom of balloonomania in Russia is that Catherine very early issued an order to the Senate banning balloon flights from March 1 to December $1,1784 .{ }^{16}$ As the empress observed herself, her main reason for issuing such a decree was her fear of fire hazard, a perfectly legitimate fear, as John T. Alexander has shown, considering the dominance of wooden constructions in Russian towns. ${ }^{17}$ Yet Catherine's comments on the matter reveal other reasons for her ban. The first is her lack of interest in this technological advance. Like Sir Joseph Banks and several British commentators before her, she considered aerostation as childish and socially useless. $^{18}$

The second may have been related to Russia's own conception of its geopolitical status. Parisian aeromania was partly fuelled by the way France regarded itself as a military power. Indeed, France's conquest of the air was fantasized as a response to Britain's rule over the seas, an aspect clearly perceived by the authors of British satirical prints, who drew imaginary French attacks from the air (Figure 2). ${ }^{19}$

\footnotetext{
${ }^{12}$ Alexander, 502-03, 509. According to the Chronicle of the Academy of Sciences, on May 10, 1784, the Academicians read and discussed a report written for the Paris Academy of Sciences on the machine of the Montgolfiers, and sent by Princess Dashkova. See Letopis' rossiiskoi akademii nauk, ed. N. I. Nevskaia, vol. 1, (St. Petersburg: Nauka, 200o), 710. In 1783, Nestor Ambodik also published his translation of a French text on balloons under the title Razsuzhdenie o sharakh goriuchim veshchestvom napolnennykh $i$ po vozdukhe [sic!] letaiushchikh, ili vozdukhonosnykh, izobretennykh g. Mongolfierom v Parizhe. See Svodnyi katalog russkoi grazhdanskoi pechati 1725-180o, vol. 3, (Moscow: Kniga, 1966), 18, \#5862.

${ }^{13}$ Alexander, 502.

${ }^{14}$ Alexander, 503.

${ }^{15}$ Alexander, 506-08.

${ }^{16}$ Alexander, 510.

${ }^{17}$ Alexander, 510-11.

${ }^{18}$ Alexander, 504. On British doubts regarding the social utility of balloons, see Keen, 513.

${ }^{19}$ Keen, 527. Keen comments on a British satirical print that depicts a French (cultural) attack on Britain (and its cultural values). What was a source of anxiety in Britain was oppositely an instrument of French military ambitions across the Channel. Between 1803 and 1805, when Napoleon was considering invading Britain from his Camp de Boulogne, a French anonymous engraving, entitled "Divers projets sur la descente en Angleterre" ("Various projects regarding the invasion of England"), staged various ways of invading the island, including the use of hot air balloons.
} 


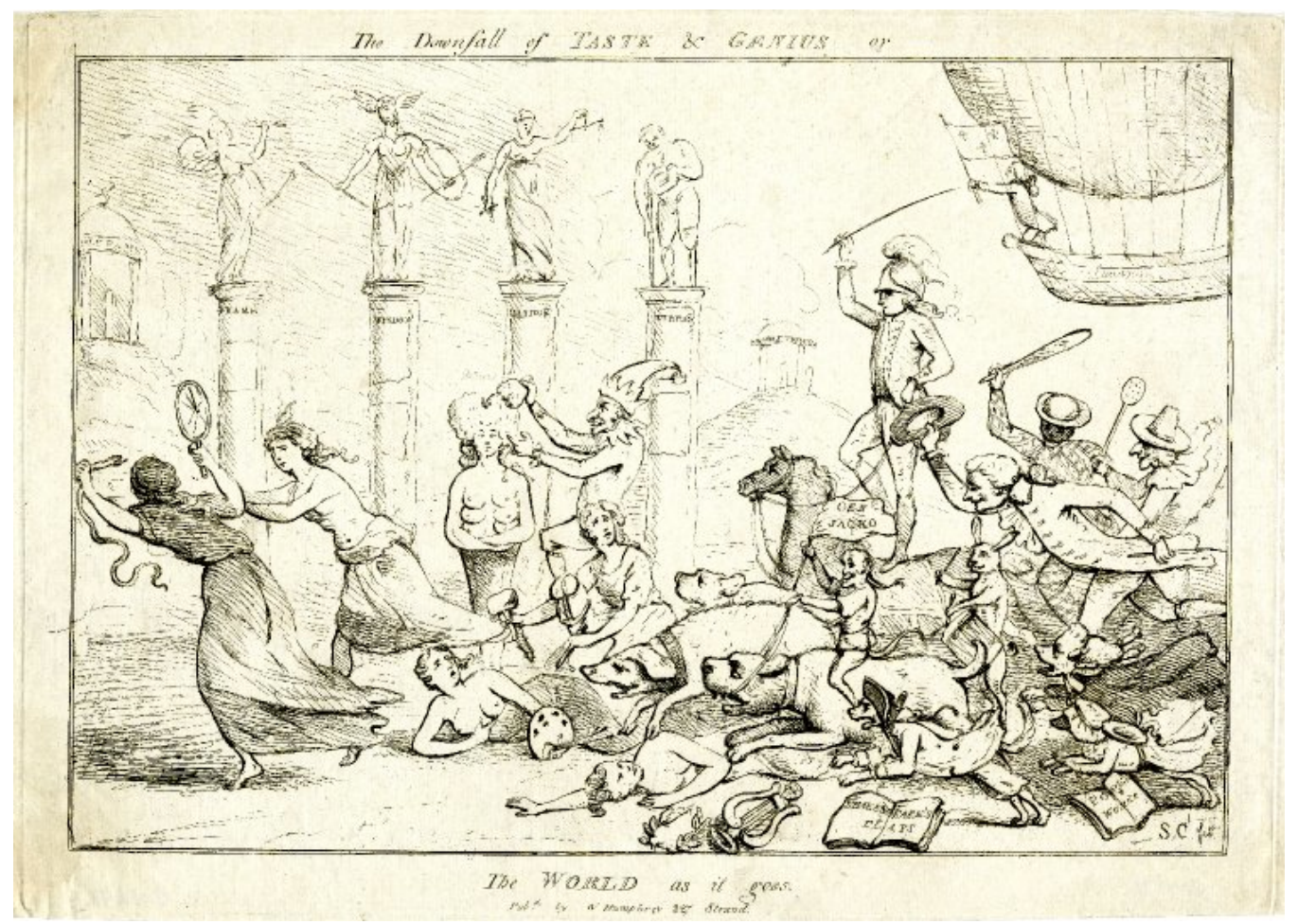

Fig. 2: Samuel Collings, The downfall of taste $\mathcal{E}$ genius or the world as it goes, 1784. ㄷ The British Museum.

This aspect was also perceived by Frederick the Great, who observed that Britain ruled over the seas and France in the sky. As for Austria and Russia, they were, according to him, mainland powers. ${ }^{20}$ It is very likely that Catherine shared Frederick's perception, and therefore had no interest in conquering the skies, especially since recent victories in Poland and the Crimea had confirmed the ability of her troops to achieve success on the ground.

Strangely enough, it seems that Catherine failed to see in the new invention a tool for space management, an acute problem for the Russian empire, as the dramatic failure of the government to rapidly crush Pugachev's rebellion had shown a few years earlier. ${ }^{21}$ True, the empress' sole positive comments on hot air balloons in her correspondence with Grimm do concern their expected future ability to fulfil her wish to bring him to Petersburg in no time. ${ }^{22}$ In this respect, Catherine's reflections are reminiscent of Arkadii Morkov's impressions. In the depiction of French balloon flights which he sent to the Vorontsov brothers from Paris in September 1783, Morkov highlighted the possibility given by balloons to reduce travel time between Russia and France. ${ }^{23}$ Yet Catherine must have been aware that the main technical issue scientists and aeronauts were struggling

\footnotetext{
${ }^{20}$ Alexander, 511.

${ }^{21}$ J. M. Hartley, A Social History of the Russian Empire 1650-1825, (London: Longman, 1999), 111. On the Russian government's efforts to manage territory starting from the Petrine era, see W. Sunderland, "Imperial Space: Territorial Thought and Practice in the Eighteenth Century," in J. Burbank, M. von Hagen, A. Remnev, eds., Russian Empire. Space, People, Power, 1700-1930, (Bloomington and Indianapolis: Indiana University Press, 2007), 33-66.

${ }^{22}$ Sbornik imperatorskogo istoricheskogo obshchestva, vol. 23, St. Petersburg, 1878, 295, Letter from January 5,1784 .

${ }^{23}$ Alexander, 502.
} 
with was their inability to manage the direction of hot air balloons, which condemned reveries about balloon travels to the field of mere fantasies.

The third reason of Catherine's lack of interest is reminiscent of British xenophobia. Indeed, it may have been related to the fact that the man who put up the two balloon flights in Moscow, an individual called Mesnil, ${ }^{24}$ as well as the people who offered to come to Russia to demonstrate the new invention, from Montgolfier himself to Blanchard, ${ }^{25}$ were all French. Though accustomed to the fact that many French adventurers considered Russia the perfect playground for their often utopian projects, ${ }^{26}$ Catherine may have been irritated by this specific project, for it embodied futility and childishness, two features often associated with the French in Russian discourse at the end of the eighteenth century, including under Catherine's own pen. ${ }^{27}$ In one of her letters to Grimm, where she comments on balloons, she criticized Parisians for their tendency to "become passionate about new follies (marotte) every month," implicitly opposing them to the more reasonable public of her own capital. ${ }^{28}$ Understanding aerostation, as many contemporaries did, ${ }^{29}$ as a tool of French cultural imperialism, the Empress seems to have been eager to preserve her own subjects from its most foolish forms. Characteristically, she equated aerostation with mesmerism, in such a way as to characterize both as the work of fashionable charlatans, who should not be allowed to fool the Russian public as they did with the French one. ${ }^{30}$

Last, but not least, the empress may have been worried by the trouble, which balloon flights could cause to public order. ${ }^{31}$ Such troubles had occurred many times, from the

\footnotetext{
${ }^{24}$ In his study, John T. Alexander expresses doubt about whether the man was called Menil or Dumenil. In their dictionary of French people living in eighteenth-century Russia, Anne Mézin and Vladimir Rjéoutski identified the man as Mesnil (with an s). See their Les Français en Russie au siècle des Lumières, vol. 2, (Ferney-Voltaire: Centre international d'étude du XVIII siècle, 2011), 595-96. The author of the article on Mesnil in the dictionary is Aleksandr Chudinov, who also authored a paper largely devoted to Mesnil's attempts and, more generally, to the interest for aeronautics shown by various French teachers living in Russia in the 1780 s, including Gilbert Romme and his compatriot Ignace James. See A. Chudinov, "Polety nad Moskvoi (francuzy-guvernery i pervye opyty vozduhoplavaniia v Rossii XVIII v.)," in Homo Historicus. K 8o-letiiu Iu. L. Bessmertnogo, vol. 2, (Moscow; Nauka, 2003), 209-23. I thank Aleksandr Chudinov and Vladislav Rjéoutski for providing me with a copy of this paper. Among other precious information, Chudinov notes that the French fashions triggered by aeromania, which had caused British anxieties, were reported by the Moskovskie vedomosti (209).

${ }^{25}$ Alexander, 505, 514.

${ }^{26}$ On this, see A. Stroev, Te, kto popravliaet fortunu. Avantiuristy Prosveshcheniia, (Moscow: NLO, 1998); R. Bartlett, "Utopian and projectors in eighteenth-century Russia," in ed. R. Bartlett, L. Hughes, Russian Society and Culture and the Long Eighteenth Century. Essays in Honour of Anthony G. Cross, (Münster: Lit; New Brunswick: Transaction Publishers, 2004), 98-115.

${ }^{27}$ On the fight against gallomania in eighteenth-century Russia, see H. Rogger, National Consciousness in Eighteenth-Century Russia, (Cambridge MA: Harvard University Press, 1960). On Catherine's criticism of gallomania in her comedies, see L. Donnels O'Malley, The Dramatic Works of Catherine the Great: Theatre and Politics in Eighteenth-Century Russia, (Aldershot: Ashgate, 2006), 123-125.

${ }^{28}$ Sbornik imperatorskogo istoricheskogo obshchestva, 306. Letter from May 8, 1784.

${ }^{29}$ M. Gyung Kim, The Imagined Empire: Balloon Enlightenments in Revolutionary Europe, (Pittsburgh, University of Pittsburgh Press, 2016), 261.

${ }^{30}$ In her May 8, 1784 letter to Grimm, she writes that she does not care for balloons any more than she does for the work of "the charlatan who cures vapours," meaning Mesmer. See Sbornik imperatorskogo istoricheskogo obshchestva, 306. Similarly, after his first (failed) flight attempt, Mesnil was largely considered as a charlatan by the Moscow nobility. On this, see Chudinov, 216. On Catherine's equation of aeronauts with conjurors, see Collis, 512.

${ }^{31}$ Alexander, 513; Collis, 512.
} 
reaction of French peasants in Gonesse, who met Charles' balloon with stones and pitchforks when it landed after its initial flight on August 27, 1783 (Figure 3), ${ }^{32}$ to the crowd's burst of violence after Abbé Miolan's failed flight in Paris on July 11, 1784 .

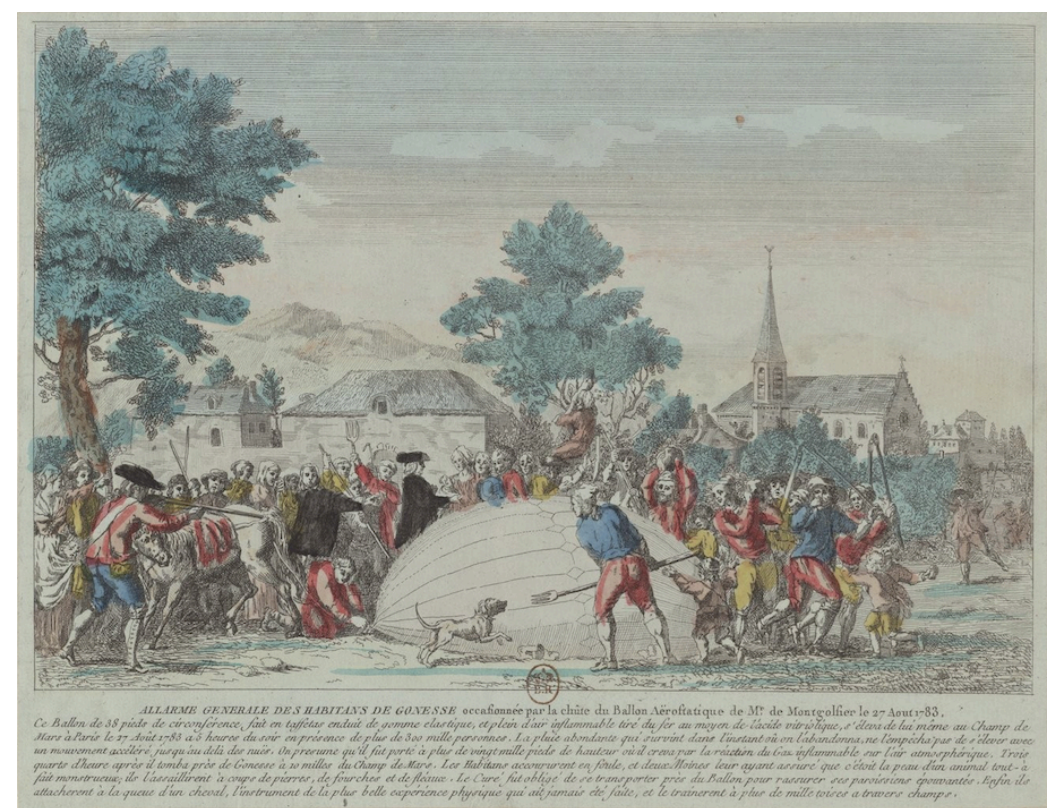

Fig. 3: Alarme générale des habitans de Gonesse. Anonymous colored engraving, 178? @ Gallica, BNF.

This event was well known to Catherine, as it had been largely publicized in the French and European press, including in the July 31, 1784 issue of the Moskovskie vedomosti. ${ }^{33}$ It was also the subject of one of the dispatches which Catherine received from Prince Ivan Bariantiskii, Russia's ambassador in France. ${ }^{34}$

\section{Miolan's flight attempt and Karamzin's narrative in "Letters of a Russian Traveler".}

\footnotetext{
${ }^{32}$ A. Sircos, Th. Pallier, Histoire des ballons et des ascensions célèbres, (Paris: F. Roy, 1876), 36.

${ }^{33}$ Alexander, 513. See Moskovskie Vedomosti, 31 iiunia, 1784 g.:

Franciia

$[\ldots]$

Ottudazh ot 12 iiulia
}

"Desiatago chisla sego mesiaca obiavleno bylo v Parizhskom zhurnale, chto Gospoda Miolan i Zhaninet poletiat 11 chisla na vozdukh s vozdushnym sharom, sovsem novago izobreteniia, iz sadu Luksemburgskago Dvorca. Na sei konets sobralos' tuda do 15 tysiach' zritelei. Kazhdyi iz nikh zaplatil za vkhod po 3 livra, a za inyia mesta zaplacheno bylo i po 6 livrov. Shar sdelan byl iz 3700 arshin kholstyni, i imel v popereshnike svoem 264, a v vyshinu 100 futov. Mezhdu znatneishimi zriteliami nakhodilsia i Graf Gaga. Chasa s 3 dozhidalis' voskhozhdeniia vozdushnago shara, no v sie vremia edva mogli napolnit' goriuchim vozdukhom 25 futov onago. Gaga vyshel posle togo iz sobraniia. Vozdushnye puteshestvenniki skrylis' k velikomu svoemu schastiiu; ibo v protivnom sluchae oni ne izbezhali by iarosti naroda, kotoroi, ne smotria na karaul, razorval shar na tysiachu chastei i perelomil vse stul'ia, lestnitsy i pr. - Khotia by sie / proishestvie vylechilo nas ot neduga, predprinimat' puteshetviia po vozdukhu!" I thank Andrei Kostin for providing me with a copy of this article.

${ }^{34}$ N. Galitzyne, "Les premières expériences de Montgolfier, d'après des documents russes," Annales internationales d'Histoire, Congrès de Paris, 1900. $5^{e}$ section: Histoire des sciences, (Paris: A. Colin, 1901), 152-53. Dispatch from July 11, 1784. 
Miolan was an abbot and a lecturer in physics with a personal interest in aerostation. ${ }^{35}$ (Figure 4)

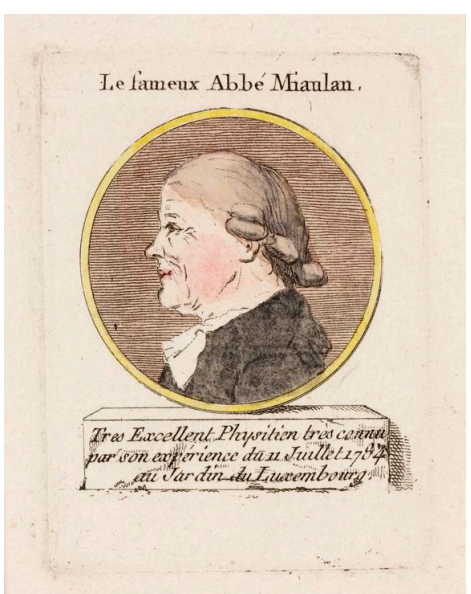

Fig. 4: Le Fameux abbé Miaulan, Anonymous colored engraving, 1784, ㅇ The Science Museum.

From late June to early July, 1784 , the Journal de Paris paper had repeatedly announced that Miolan would launch the biggest balloon ever made from the Luxembourg Garden, with the help of his assistant Janinet. ${ }^{36}$ As often with balloon launches, a public subscription was organized and tickets sold from 3 to 6 livres. ${ }^{37}$ (Figure 5)

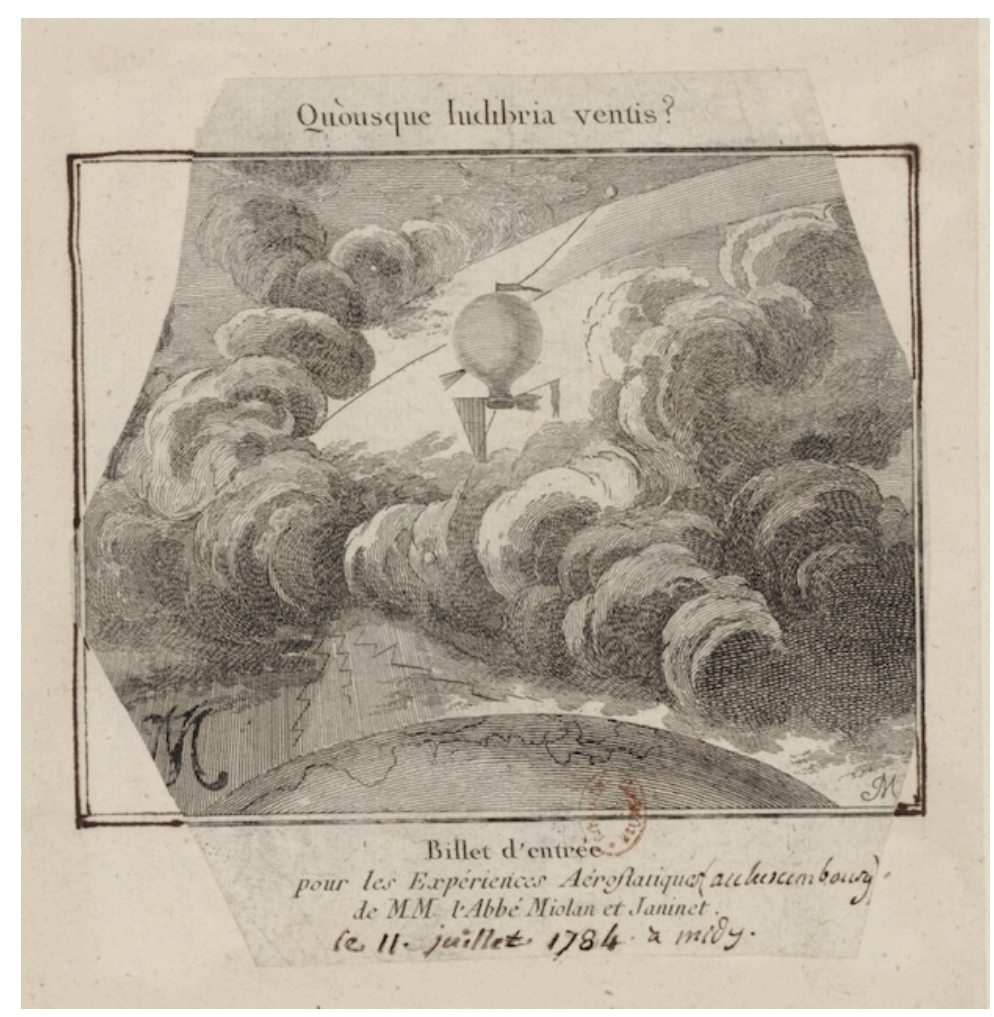

\footnotetext{
${ }^{35}$ Gyung Kim, 184.

${ }^{36}$ Le Journal de Paris \# 172 (June 20, 1784, 740), \# 177 (June 25, 1784, 760-761), \# 776 (June 29, 1784, 776), \# 184 (July 2, 1784, 787-788), \# 189 (July 7, 1784, page 8o8), \# 191 (July 9, 1784, 816), \# 192 (July 10, 1784, 819820), \# 193 (July 11, 1784, 824). Quoted in Sircos and Pallier, 186-87.

${ }^{37}$ Le Journal de Paris, \# 192, July 10, 1784, 820.
} 
Fig. 5: Billet d'entrée pour les experiences aérostatiques de MM. l'abbé Miolan et Janinet, 1784 @ Gallica, BNF.

Even the royal family announced its intention to attend, before cancelling. This muchpublicized event nevertheless attracted huge crowds, including Gustav III of Sweden, under the pseudonym of Count of Haga. ${ }^{38}$ Despite Miolan's efforts to launch his balloon, the experiment failed, which provoked the fury of the crowd, overheated by the July sun. ${ }^{39}$ As in previous failed attempts, including in Britain, ${ }^{40}$ people rushed at the balloon and tore it into pieces, while Miolan used the general mayhem to escape. ${ }^{41}$ (Figure 6)

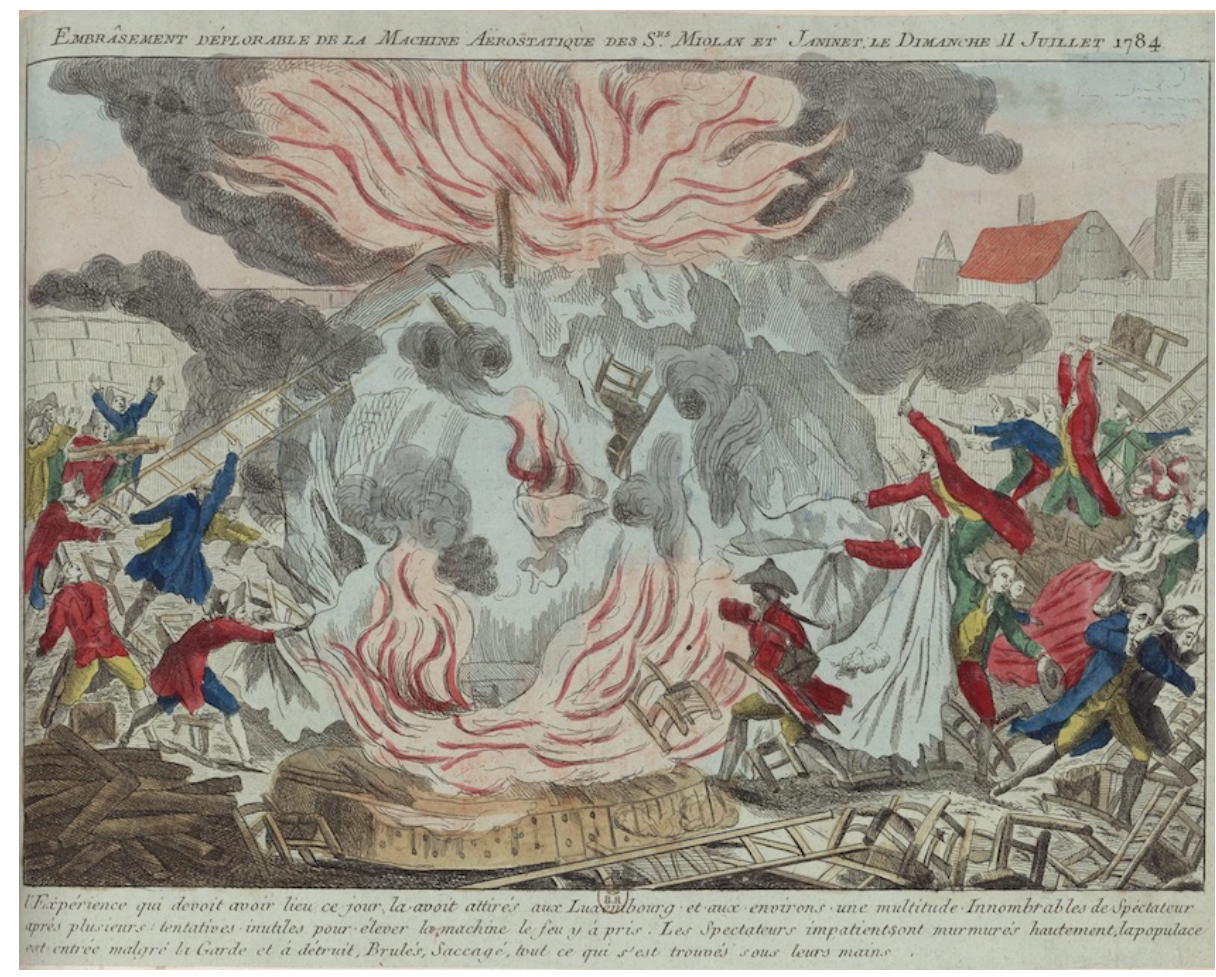

Figure 6: Embrasement deplorable de la machine aérostatique des Srs Miolan et Janinet le dimanche 11 juillet 1784, (c) Gallica, BNF.

After the event, people called Miolan a charlatan, suspecting him to have known that his balloon would never fly, and accusing him of having organized the event with the sole purpose of collecting the subscription money. ${ }^{42}$ Satirical prints circulated, mocking the abbot under the appearance of a cat, a pun based on the abbot's last name (Miolan was intentionally misspelled as "Miaulant," which translates as "meowing"), as well as an allusion to his malice (Figure 7).

\footnotetext{
${ }^{38}$ Sircos and Pallier, 188.

${ }^{39}$ Sircos and Pallier, 188.

${ }^{40}$ Gillespie, 263.

${ }^{41}$ Sircos and Pallier, 188 . An equally unsuccessful flight attempt organized by a Professor Cerny in Moscow in October 1802 triggered a similar reaction from the crowd. On this, see Collis, 513.

${ }^{42}$ L. P. de Bachaumont, Mémoires secrets pour servir à l'Histoire de la République des Lettres en France, vol. 26, (Londres, 1786), 108 (“22 juillet"), 120 (“27 juillet").
} 


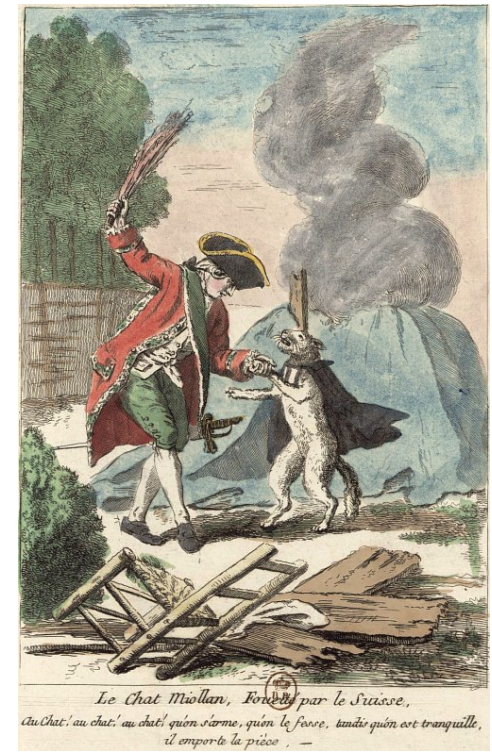

Fig. 7: Le Chat Miaulan, fouetté par le Suisse, 1784 (c) Gallica, BNF.

Additionally, songs also circulated that mocked the abbot's amateurism and his misplaced ambition to appear as a man of science. ${ }^{43}$ (Figure 8)

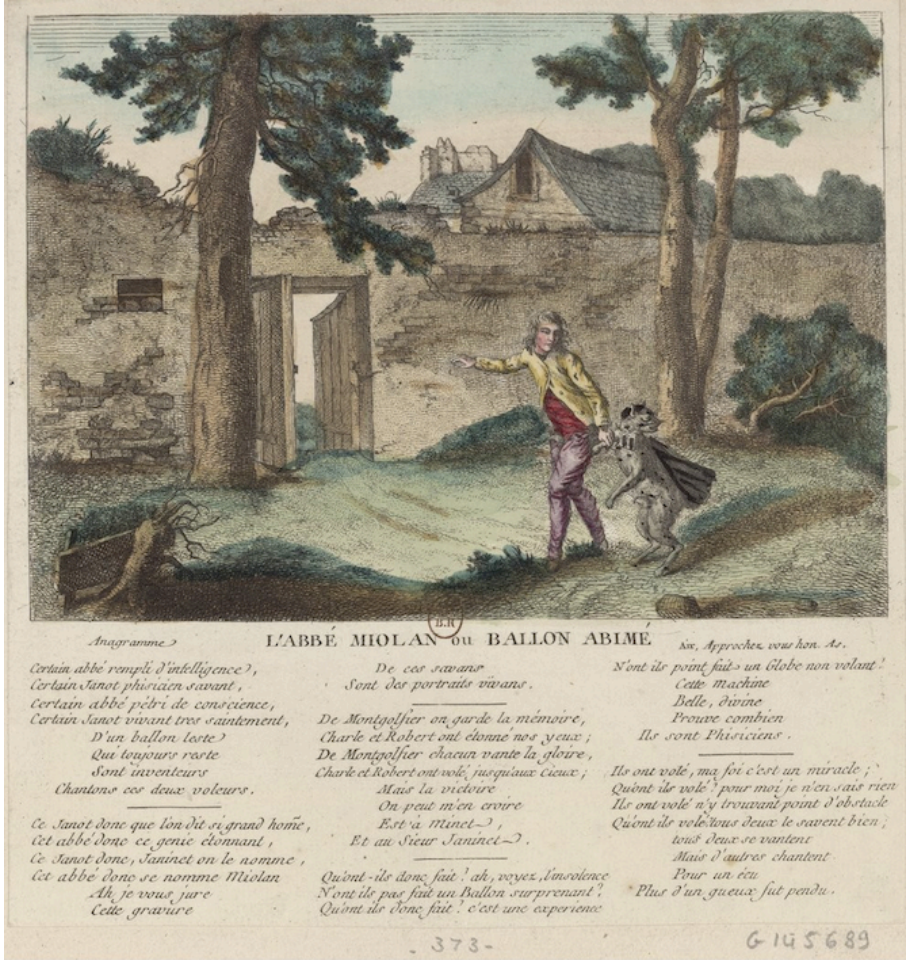

Fig. 8: L'abbé Miolan ou ballon abimé, 1784, 담 Gallica, BNF.

If Catherine knew about Miolan's misadventure, Karamzin did too, as he reported it in Letter 102 of his "Letters of a Russian Traveler." Here is what Karamzin's Russian Traveler says about it:

\footnotetext{
${ }^{43}$ Sircos and Pallier, 190-92
} 
Господин Д*, гуляя со мною третьягодни в Люксанбурском саду рассказал мне забавной случай. В 1784 году, Июля $8,{ }^{44}$ собрался там почти весь Париж, чтобы видеть воздушное путешествие Аббата Миолана, объявленное через газеты, Ждут два, три часа: шар не поднимается. Публика спрашивает, когда начнется эксперимент? Аббат отвечает: в минуту! Но приходит вечер, а шар ни с места. Народ теряет наконец терпение, бросается на аэростат, рвет его в клочки, а Миолан спасается бегством. На другой день в Пале-Рояль и на всех перекрестках Савояры кричат: “Кому надобно изображение славного путешествия, щастливо совершенного славным Аббатом Миоланом, - за копейку, за копейку!" Аббат после того умер гражданскою смертию, то есть, не смел казаться в люди. Смешная история должна была кончиться новым смешным анекдотом. Господин Д*, скоро после Миоланова бедствия, был в партере Оперы и смотрел на балет. Вдруг приходит высокой человек, Аббат, становится перед ним, и мешает ему видеть сцену. "Посторонитесь, говорят ему: здесь довольно места.” Гигант не слушает, не трогается; смотрит и не дает другим смотреть. Молодой Адвокат, который стоял подле Господина Д*, сказал ему: “хотите ли, чтобы я выгнал высокого Аббата?" Ах ради Бога! естьли можете.-“Могу”-и тотчас начал шептать на ухо всем, стоявшим вокруг его: “вот Аббат Миолан, который обманул публику!” Вдруг десять голосов повторили “вот Аббат Миолан!" Чрез минуту весь партер закричал: “вот Аббат Миолан!” и все указывали пальцом на высокого человека, который в изумлении, в досаде, в отчаянии на право и на лево кричал: “Государи мои! я не Аббат Миолан!” Но скоро и во всех ложах раздался голос: “вот Аббат Миолан!” так, что высокому человеку, который назывался совсем не Миоланом, надлежало как преступнику бежать из театра. Господин Д*, умирая со смеху, изъявлял благодарность молодому Адвокату, между тем как партер и ложи, заглушая музыку, кричали: “Вот Аббат Миолан!"45

As he walked with me in the Luxembourg gardens a few days ago, $\mathrm{Mr} \mathrm{D}^{*}$ told me an amusing anecdote. In 1784, on July 8, almost all of Paris gathered there in order to see the air voyage of the abbé Miolan, as announced in the newspapers. They wait for two, three hours: the balloon does not rise. The public asks when the experiment will begin. "In a minute," the abbé replies. But evening comes, and the balloon has not budged from the spot; the people finally lose patience, surge onto the air machine and tear it in pieces, and Miolan escapes by running away. The next day, in the Palais-Royal and at every crossroad, the savoyards shout: "If you require a depiction of the great voyage happily completed by the famous abbé Miolan, at a penny, at a penny!" After this the abbé died a

\footnotetext{
${ }^{44}$ The reason why Karamzin made a mistake about the date of Miolan's flight is unclear.

${ }^{45}$ N. M. Karamzin, Pis'ma russkogo puteshestvennika, ed. by Iu. Lotman, N. A. Marchenko, B. A. Uspenskii (Leningrad: Nauka, 1987), Letter 102, "Parizh, Maiia...", 248.
} 
citizen's death - that is, he did not dare appear in society. The funny story had to end with a new funny anecdote. Mr D*, shortly after Miolan's catastrophe, was in the pit of the Opéra watching the ballet. Suddenly there enters a tall man, an abbé; he stops in front of him and blocks his view. 'Move aside', he tells him. "There's enough space there." The giant does not listen, does not move; he watches and prevents others from watching. A young lawyer standing alongside $\mathrm{Mr} \mathrm{D}^{*}$ said to him: "Do you want me to get rid of the tall abbé?" "Ah, for God's sake! If you could." "I can," and with that began to whisper into the ears of all standing around him, "That's the abbé Miolan who deceived the public!" Suddenly ten voices repeated, "There's the abbé Miolan!" In a minute the entire pit had begun to shout, "There's the abbé Miolan!" and everyone pointed at the tall man, who in surprise, vexation and desperation cried out right and left: "Sirs! I'm not the abbé Miolan!" But soon the cry rang out, "There's the abbé Miolan!" from all the boxes, so the tall man - whose name was certainly not Miolan - had to flee from the theatre like a criminal. Mr D*, expiring with laughter, expressed his gratitude to the young lawyer while the pit and boxes drowned out the music, shouting: "There's the abbé Miolan!" 46

As this long quote suggests, Karamzin's information about Miolan's failure was accurate. Besides the report from Moskovskie vedomosti, which he may, or may not have read, since it was published several years before he started writing his "Letters of a Russian Traveler," he may have heard about it from various sources, chronologically closer to the 1790 .

As Andrew Kahn has noted, the story of Miolan was known to Louis-Sebastien Mercier, who mentions it in the tenth volume of his "Tableau de Paris," ${ }^{7}$ a work published in 1788 and which Karamzin widely used as a source of information for the part of his "Letters" dedicated to life in the French capital. ${ }^{48}$ Mercier's narrative, however, is short and allusive. Miolan's story is used merely as a comparison between the abbot's fate and that of unsuccessful playwrights. ${ }^{49}$ As such, Mercier's account focuses entirely on the aftermath of Miolan's failed attempt and its social consequences. Therefore, it seems unlikely that the "Tableau de Paris" may have inspired Karamzin this time.

A more plausible source seems to be another book, which Vladimir Sipovskii identified as one of Karamzin's main sources of information on Paris: Jacques-Antoine Dulaure's "Nouvelle description des curiosités de Paris," which came out in $1787 .{ }^{50}$ The very context in which Karamzin tells about Miolan's story is reminiscent of Dulaure. Indeed, Karamzin's mention of the anecdote is not triggered by an analogy, as in Mercier's account, but follows the logics of geography, like in the "Nouvelle description." Just like his French predecessor, the Russian writer evokes Miolan while describing the Luxembourg Garden for his readers:

\footnotetext{
${ }^{46}$ N. Karamzin, Letters of a Russian Traveller, A translation and study by Andrew Kahn, (Oxford: Voltaire Foundation, 2003), Letter 102, 288.

${ }^{47} \mathrm{Kahn}, 288$.

${ }^{48}$ V. V. Sipovskii, N. M. Karamzin, avtor "Pisem russkogo puteshestvennika," Zapiski istorikofilologicheskago fakul'teta imperatorskago s.-peterburgskago universiteta, vol. 49, (St. Petersburg: 1899), 262-72.

${ }^{49}$ L. S. Mercier L.-S., Tableau de Paris. Nouvelle édition, corrigée et augmentée, vol. 10, (Amsterdam, 1788), 65.

${ }^{50}$ Sipovskii, 293-305.
} 
C'est au milieu de ce terrein abandonné que M. l'Abbé Miolan fit au mois de Juillet 1784 , l'expérience publique \& mémorable de son inexperience (1 [refers to a footnote])

(1 [footnote]) Depuis 11 heures du matin jusqu'à 5 heures du soir, une prodigieuse foule de curieux de tous les états attendoient, pour leur argent, l'enlevement du malheureux Ballon qui ne s'enleva pas. Tout Paris s'étoit porté dans ce quartier, \& en avoit absorbé les vivres. La faim, la chaleur, l'impatience \& le dépit de se voir abusé éclaterent en fureur. On se jetta sur le Ballon indocile; on déchira, on brisa tout ce qui se présentoit. Les Auteurs de cette inexpérience échapperent aux flammes ; mais non pas à la vengeance des Parisiens. Comme ces Phisiciens ne firent, pour appaiser le public, aucune espece de restitution, on s'est amplement dédommagé aux dépens de la gloire de l'Abbé Miolan, \& de son confrere : les chansons \& les caricatures de tous les genres ont acquité la dette des Aérostasticiens par souscription. Dans l'anagrame d'Abbé Miolan, les plaisans on trouvé Balon abîmé..$^{1}$

It is in the middle of this vacant lot that Mr l'Abbé Miolan, in July 1784, put up the experience which gave the public and memorable proof of his inexperience (1 [refers to a footnote]).

( 1 [footnote] From 11 in the morning until 5 in the afternoon, a huge crowd of curious people from all estates awaited, in exchange of their money, the rise of the unfortunate balloon, which eventually did not rise. All Paris had come to this neighbourhood \& had consumed all the food there. Hunger, heat, impatience \& bitterness at the thought of having been fooled all burst into fury. People rushed at the disobedient balloon, tore into pieces and broke all they could put theirs hands on. The men responsible for this inexperience escaped from the flames, but not from the revenge of the Parisians. As these physicists did not return any of the money they had perceived in order to calm down the public, people sought compensation in ruining the fame of Abbé Miolan \& his colleague: songs and satirical prints of all kinds have paid for the debt of the aeronauts by subscription. In the anagram of Abbé Miolan, witty people have found Balon abîmé.

Apart from the anagram at the end of the French text, Karamzin's account is very similar to Dulaure's. ${ }^{52}$ The Russian text, however, exceeds the story of the unsuccessful launch and of Miolan's social condemnation and punishment at the center of Dulaure's narrative. It triggers an additional one, focused on a secondary use of Miolan's story in a different social context, that of an evening at the theater. Despite being allegedly told to

\footnotetext{
${ }^{51}$ J.-A. Dulaure, Nouvelle description des curiosités de Paris, Seconde édition, (Paris, 1787), 118-19.

${ }^{52}$ The absence of the anagram in Karamzin's account comes as a surprise, considering Karamzin's interest in the various expressions of French wit. While entering French territory, for instance, the narrator notes about the absence of soup in the usual meal of French provincial inns: "On soupe sans soupe." See N. M. Karamzin, Pis'ma russkogo puteshestvennika, Letter 88, “6 marta, 179o”, 194. Karamzin’s reluctance to mention the anagram about Miolan could be explained by the conviction that an anagram has a limited temporal value and loses its flavor when the context that produced it vanishes.
} 
Karamzin's narrator by his Paris acquaintance Mr. $\mathrm{D}^{*}$, this anecdote does seem to have a literary origin. It was told by Mirabeau to Chamfort in a letter from 1784 , available to the reading public in Mirabeau's collection of letters, published in Paris in Year V, that is the very year Karamzin issued the part of his "Letters" containing the episode about Miolan: ${ }^{53}$

Ne vous attendez pas que je vous donne de grandes nouvelles de ce pays, où vous avez à coup sûr de meilleurs correspondans que moi. Voici cependant un lazzi que je vous fais passer, parce que je le tiens de la première main. Un grand Abbé que vous connaissez peut-être, frère de Sabathier, de Castre, que vous connaissez sûrement, était avant-hier aux Variétés-Amusantes, devant un très-petit homme, qui lui a fait la prière usitée en pareil cas. Monsieur, a répondu l'Abbé, chacun est ici pour son argent, et je garde ma place. - Mais, Monsieur, je ne puis pas vous nuire, et vous me privez du spectacle. - Monsieur, j'en suis faché, et je garde ma place. - Je vous assure, Monsieur, qu'il est de votre intérêt d'être plus complaisant. - Comment, Monsieur, que voulez-vous dire ? - Que je suis persuadé qu'il vous arrivera quelque chose de désagréable, si vous ne déférez pas à ma prière. - Comment, Monsieur, vous me menacez ! - Dieu m'en garde, Monsieur ; mais si vous ne me cédez pas votre place, vous vous en repentirez. - Parbleu, voilà une manière nouvelle de prier les gens ; et certes elle ne réussira pas. - Monsieur, faites bien vos réflexions ; car il vous arrivera malheur si vous ne passez derrière moi. - Monsieur, laissez-moi en repos... Alors, le petit homme dit à son voisin : voyez-vous ce grand Abbé ; c'est l'abbé Miolan. - L'abbé Miolan! - Oui, l'abbé Miolan, le grand constructeur de ballons brûlés. - Messieurs, voyez-vous l'abbé Miolan ? (1) - L'abbé Miolan! Toute la salle répète en écho, l'abbé Miolan, et les battemens de mains ; et les huées ; et les miau, miau, miau. Le grand Abbé s'enfuit, trop heureux de n'être pas écrasé... Certainement le petit homme n'était pas bête ; et le grand Abbé n'est pas poli. ${ }^{54}$

Don't expect me to give you any big news about this country, where you probably have better correspondents than me. Here is, however, a lazzi which I communicate to you because I heard it from its very source. A tall Abbé you may know of, Brother Sabathier, from Castre, which you probably know too, was yesterday at the Variétés Amusantes, sitting in front of a very small man, who addressed him with the usual demand in such cases. Sir, answered the Abbé, everybody here paid for his seat and I will keep mine. - But, Sir, I cannot be of any inconvenience and you are depriving me of the show. - Sir, I do regret this, but I'll keep my seat. - I assure you, Sir, that it is in your best interests to be more obliging. - How is that, Sir, what do you mean? - That I am convinced that something unpleasant will happen

\footnotetext{
${ }^{53}$ Year V went from September 1796 to September 1797. The main part of Karamzin's “Letters" devoted to his narrator's stay in Paris, including letter 102, at the center of this study, were published in 1797. On the chronology of Karamzin's publication of his "Letters," see N. A. Marchenko, "Istoriia teksta 'Pisem russkogo puteshestvennika'," in Karamzin, 607-12.

${ }^{54}$ Lettres de Mirabeau à Chamfort, imprimés sur les originaux écrits de la main de Mirabeau, (Paris, An V), June 22, 1784, 13-15. The date of the letter in this early edition is obviously erroneous; it must have been July 22, not June, as Miolan's aborted flight happened on July 11.
} 
to you if you don't accept my demand. - What, Sir, are you threatening me? - God forbid, Sir, but if you don't give me your seat, you will be sorry for it. - Bly me, this is a very unusual way to ask people for something, and it certainly will not succeed; Sir, do think about it, for you will come to grief if you don't go and sit behind me. - Sir, leave me alone... Then the small man told his neighbour: do you see this tall Abbé? it's Abbé Miolan. - Abbé Miolan! - Yes, Abbé Miolan, the great constructor of burning balloons. Gentlemen, do you see Abbé Miolan? - Abbé Miolan! The entire room repeated in an echo, Abbé Miolan and they started clapping their hands, booing and mewing miau, miau, miau. The tall Abbé ran away, too happy not to have been trampled on... Undoubtedly, the small man was no fool; and the tall Abbé is rude.

Despite its simplification under Karamzin's pen, and his rewriting as an original anecdote told by an actual acquaintance-a literary strategy used repeatedly in "Letters of a Russian Traveler" — 55 it seems very likely that the origin of Karamzin's second anecdote on Miolan lies in Mirabeau's letter to Chamfort, two figures the Russian writer was definitely interested in, the first as a major political actor of the French Revolution, ${ }^{56}$ the second as one of the writers Karamzin mentioned in his account of French literature in Revolutionary Paris. ${ }^{57}$

Obviously inspired by Dulaure's use of anecdotes to make geography livelier and by Mirabeau's taste for samples of Parisian wit, Karamzin seems to have missed entirely that Miolan's story was also a story about aeromania, a phenomenon both contemporary and French, which, as such, could have interested Russian readers hungry for novelty coming from Europe.

\section{From Liberty to Social Disciplining: A Political Reading of Aeromania.}

Indeed, Karamzin obviously did not care for aerostation. The reason for this lack of interest could lie in Karamzin's overall indifference to sciences, a consequence of the specific education he had received in Schaaden's pension in Moscow, where the curriculum was mainly focused on the humanities. ${ }^{58}$ While in Paris, considered as the European capital of sciences in the eighteenth century, ${ }^{59}$ he scarcely visited any scientific institutions, and his mentions of prominent scientists, such as Lavoisier or the explorer Vaillant are usually limited to information on their social life as public figures. ${ }^{60}$ Yet hot air balloons were not mere science. As mentioned earlier, their ambiguous nature made

\footnotetext{
${ }^{55}$ See, for instance, R. Boden [Baudin R.], "Literatura i politika. Karamzin, Rable i poetika frantsuzskoi revoliutsii v 'Pis'makh russkogo puteshestvennika'," XVIII vek, vyp. 29, (Moscow-St. Petersburg: Ali'ansArkheo, 2017), 230-51.

${ }^{56}$ N. Karamzin, Letters of a Russian Traveler, 371. On Karamzin's opinion of Mirabeau, see L. G. Kisliagina, “The development of N. M. Karamzin's social political views," in ed. J. L. Black, Essays on Karamzin: Russian Man-of-Letters, Political Thinker, Historian, 1766-1826, (The Hague-Paris: Mouton, 1975), 98.

${ }^{57}$ N. Karamzin, Letters of a Russian Traveler, 296.

${ }^{8}$ R. Baudin, Karamzin en France. L'image de la France dans les Lettres d'un voyageur russe, (Paris: Institut d'Etudes slaves, 2014), 25; Kahn, 488. On Karamzin's education in Schaaden's boarding school, see Cross, 1-2; Bulich, "Karamzin v pansione Shadena," in ed. V. I. Pokrovskii, Nikolai Mikhailovich Karamzin. Ego zhizn' i sochineniia, (Moscow: Tipografiia G. Lisnera I D. Sovko, 1908), 23-6.

${ }^{59}$ Belhoste, 75 .

${ }^{60}$ Baudin, 2014, 26.
} 
them both science and spectacle, or spectacular science, a type of cultural practice Karamzin was not indifferent to, as can be seen from his interest in Abbot Sicard's work with deaf-mutes for instance. ${ }^{61}$ But Sicard's public lessons were fashionable in 1790, after the death of Sicard's predecessor de l'Epée in December 1789 had attracted the attention of the public onto sign language and the moving condition of deaf-mutes. Balloons, on the contrary, were a trend long gone by. It had been at the center of public attention in $1783-1784$, but by the 1790 os the fashion for aerostation was gone, despite their use as a strategic tool at the Battle of Fleurus in $1794 .{ }^{62}$

If still present in the cultural imagination, balloons were relevant no longer as groundbreaking scientific objects, but as discursive metaphors. This was especially true in Russia because of Catherine's ban. By the time Karamzin referred to them in "Letters of a Russian Traveler," other prominent Russian writers, such as Gavrila Derzhavin, Ivan Dmitriev or Alexander Radishchev, used them with a similar function.

In Derzhavin's 1789 poem "On fate" ("Na shchast'e"), they are used as a metaphor of fate, which goes up and down, and cannot be guided. ${ }^{6}{ }_{3}$ In Dmitriev's 1798 epigram "Na spusk Stefaniem trekh sharov, v prisutstvii trekh znatnykh osob" ("On the occasion of the launch of three balloons by Stefani in the presence of three famous people"), the fall of the three balloons is likewise used as a metaphor of political disgrace. ${ }^{64}$ Finally, Radishchev keeps on using the balloon metaphor throughout his entire work. In the "Journey from Petersburg to Moscow" ("Puteshestvie iz Peterburga v Moskvu"), balloons, which rise high but fall easily, are used as a metaphor of the illusion of military glory. ${ }^{65}$ In "On Man, His Mortality and Immortality" ("O cheloveke, o ego smertnosti i bessmertii"), the philosophical treatise he wrote in his Siberian exile during the 179os, Radishchev compares existence and the relations between the soul and the body to balloons, which fly thanks to the forces of all the elements that constitute them. ${ }^{66}$ Finally, in Radishchev's

\footnotetext{
${ }^{61}$ R. Boden, [R. Baudin], "Puteshestvennik u abbata Sikara: k voprosu ob interese k glukhonemym v kul'ture russkogo sentimentalizma," in ed. N. Kochetkova, A. Veselova, R. Boden [R. Baudin], Karamzinpisatel', (St. Petersburg: Pushkinskii dom, 2018), 61-80.

${ }^{62}$ On Fleurus, see Sircos and Pallier, 255-58. Balloon flights continued to be organized throughout Europe until the turn of the 178 os and 179os, but, as Mi Gyung Kim has shown, these displays were taking place at the cultural margins of Europe, not in centres such as Paris or London. See Gyung Kim, 260-61. An exception seems to be the launch of a balloon in Paris in late May 1790, an event Pavel Stroganov reported on in his correspondence with his father. The absence of any reference to this event in Karamzin's "Letters of a Russian Traveler", however, confirms my point. On Stroganov's account, see Chudinov, 219. For the account itself, see A. Chudinov, "Zh. Romm i P. Stroganov v revoliutsionnom Parizhe (1789-179o)", Rossiia i Franciia XVIII - XX veka, vol. 2, (Moscow: Nauka, 1998), 61. In Russia, balloon flights became fashionable much later than in France and England, after Catherine's ban was lifted during the early years of the reign of Alexander I. On this later period, see Smoliarova and Collis, 512-517.

${ }^{63}$ G. R. Derzhavin, Stikhotvoreniia, (Leningrad, Sovetskii pisatel', 1957), 124-30. According to the editor of this volume, Derzhavin wrote his poem in 1789 , though Derzhavin himself presented it as a work written in 1790. On hot air balloons in Derzhavin's poetry, see T. Smoliarova, Zrimaia lirika. Derzhavin, (Moscow: NLO, 2011), 27-30.

${ }^{64}$ I. I. Dmitriev, Polnoe sobranie stikhotvorenii (Leningrad: Sovetskii pisatel', 1967), 334. I thank Nikolai Gus'kov for drawing my attention on this epigram. It is not clear who the Stefanij from Dmitriev's epigram is. According to Andrey Dobritsyn, the epigram probably does not refer to any real event, and the name Stefanij in it may just be the Russified form of the name of one of the Mongolfier brothers, Etienne. I thank Andrei Dobritsyn for this suggestion.

${ }^{65}$ A. N. Radishchev, Puteshestvie iz Peterburga v Moskvu, in Polnoe sobranie sochinenii, volume 1, (Moscow-Leningrad: AN SSSR, Institut russkoi literatury: Pushkinskii dom, 1938), "Khotilov," 317.

${ }^{66}$ A. N. Radishchev, O cheloveke, o ego smertnosti i bessmertii, in Radishchev, volume 2, (MoscowLeningrad: AN SSSR, Institut russkoi literatury: Pushkinskii dom, 1941), 106.
} 
late poem "The Eighteenth century" ("Os'mnadtsatoe stoletie"), the writer lists balloons among the inventions of men which made the eighteenth century brilliant, despite it finishing in the bloodbath of the French Revolution. ${ }^{67}$ If Radishchev's more developed metaphors, notably in his philosophical treatise, clearly show that his interest in balloons as scientific objects was higher than Karamzin's, Dmitriev's or Derzhavin's, his reference are still essentially discursive. ${ }^{68}$

While Derzhavin and Radishchev used references to balloons as philosophical metaphors, Karamzin's use, like Dmitriev's, but to a larger extent, was social and political. Indeed, Karamzin's first anecdote on Miolan's unsuccessful flight attempt gathered all the elements which had triggered Catherine's social and political reading of ballooning and her consequent rejection of the phenomenon: a public subscription, which could be regarded as a scheme, as Parisians did after Miolan's failure ${ }^{69}$; the total absence of any scientific output; a crowd, dangerous by its socially mixed nature, turning violent in a public space and threatening public order.

These elements probably drew Karamzin's attention due to the specific political context in which the young Russian writer discovered France in the summer of 1789 . Angry, uncontrollable crowds in public spaces were what Karamzin had witnessed in Strasbourg in August 1789 (Figure 9), and what had hastened his departure to Switzerland..$^{70}$

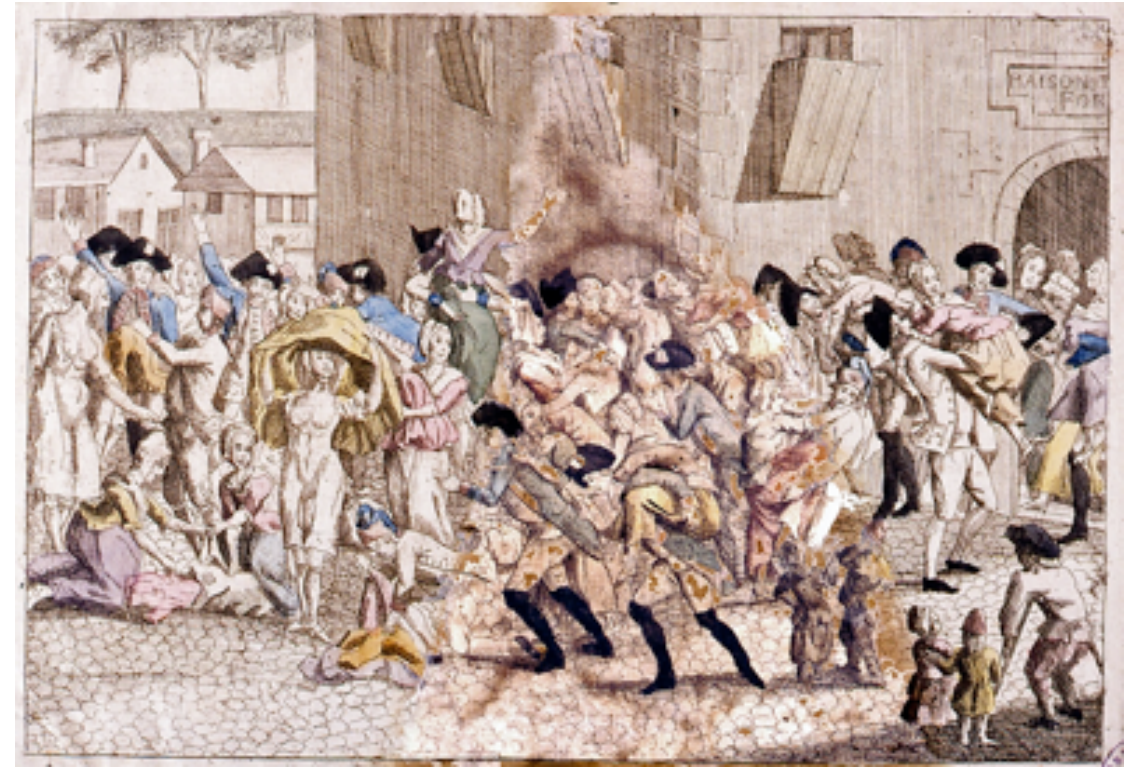

\footnotetext{
${ }^{67}$ A. N. Radishchev, Os'mnadtsatoe stoletie, in Radishchev, volume 1, 128. I thank Andrei Kostin for drawing my attention on Radishchev's references to hot air balloons in the Journey and the poem The Eighteenth Century. For additional proof of Radishchev's interest in hot air balloons, see the mention of his participation in a balloon launch in Tobol'sk while on his way to his Siberian exile. See P. A. Radishchev, Biografiia A. N. Radishcheva in Biografiia A. N. Radishcheva (Moscow-Leningrad, 1959), 73. I thank Andrei Kostin again for drawing my attention on this reference.

${ }^{68}$ As Sara Dickinson pointed out to me, Vasilii Levshin's New Travel (Novejshee puteshestvie) of 1784 uses the story of a flight to the moon as a narrative element and not a metaphor. It should be noted, however, that Levshin's fiction, if important as an early echo of the Russian reception of the Mongolfiers' invention, stages a flight on board a ship with eagle wings, not a hot air balloon.

${ }^{69}$ When balloonomania finally started in Russia in the early nineteenth century, local authorities authorized flights only if their organization was not commercially oriented. On this, see Collis, 516.

${ }^{70}$ R. Baudin, Nikolaï Karamzine à Strasbourg. Un écrivain voyageur russe dans l'Alsace révolutionnaire, (Strasbourg: Presses universitaires de Strasbourg, 2011), 66-72.
} 
Fig. 9: Libération des prostituées de la prison de Strasbourg, 6 août 1789, Eighteenth-century anonymous colored engraving @ $\odot$ Photo et Coll. de la Bibliothèque Nationale et Universitaire de Strasbourg.

In the Russian writer's account on Strasbourg, just as in the anecdote with Miolan, a disrespectful crowd threatened a member of the clergy, in what was a clear narrative of class transgression..$^{71}$ Additionally, this episode of violent unrest was depicted in "Letters of a Russian Traveler" as a carnivalesque reality. ${ }^{72} \mathrm{~A}$ specific aspect, in Karamzin's perception, of revolutionary unrest, carnival was also closely linked to aerostation as a form of spectacle, as balloon flights formed a frequent element of fairs, especially in countries where the new invention had not been monitored by the scientific elite. ${ }^{73}$ Characteristically, Bolotov's depiction of a flight attempt in Moscow in February 1784, took place at a fair during Mardi Gras. ${ }^{74}$

This connexion between two forms of carnival was not, however, the only link between ballooning and the Revolution. A metaphor of the eighteenth century as a time of disturbing changes, balloons became, in Thomas Carlyle's perception, a metaphor of the century's dangerous outcome, when he called them "beautiful inventions; mounting heavenward, so beautifully, so unguidably." ${ }^{25}$ This unguidability of balloons was of a scary nature, close to the political anxieties experienced by Karamzin at the beginning of the Revolution in France, and which were only confirmed by the Terror, which had hit the country when the writer worked on the French part of his travelogue. Worried by what seemed uncontrollable, both scientifically and socially, Karamzin endorsed Catherine's opinion on ballooning as the play of irresponsible people, which could cause trouble to the public order.

This shows Karamzin's adoption of Catherine's moderate Enlightenment program. For the writer, as for the Empress, progress was to be monitored by reason (that is, from Catherine's point of view, from above, $)^{76}$ instead of having the initiative rise (from Catherine's perspective, from below) from individuals who only wished to draw attention upon themselves, like Miolan. In this regard, French reactions to the Abbot, who, as a satirical song of the time went, "lost everything for wanting too much" 77 are somehow reminiscent of Russian perceptions of Radishchev's behaviour. In her memoirs, Princess Dashkova wrote that, after the publication of Radishchev's Life of Ushakov (Zhitie Ushakova) in 1789, she had warned her brother Aleksandr Vorontsov about the possible consequences of his protégé's "writing mania" ("démangeaison d'écrire"). ${ }^{78}$ Similarly, besides the anger and fear, which she notoriously experienced when reading the Journey from Petersburg to Moscow, and which made her label the writer a "rebel, worse than

\footnotetext{
${ }^{71}$ Baudin 2011, 66-72. If, in Miolan's case, the unrest seems more legitimate as the crowd was reacting to what it perceived as a fraud, the display of violence, however, was in both cases the same.

${ }^{72}$ Baudin 2011, 133-47.

${ }^{73}$ Keen, 517, 523.

${ }^{74}$ Alexander, 506.

${ }^{75}$ Keen, 508.

${ }^{76}$ In his letters to Gilbert Romme, Ignace James noted that Mesnil's attempts in Moscow had been financed by the local nobility, which could have been a cause of worry for Catherine, eager as she was to monitor the Enlightenment in Russia. On the financing of Mesnil's experiment, see Chudinov, 216. Mi Gyung Kim also noted that flight demonstrations could cause worry to monarchs as they appeared as a form of polity, replacing the king-machine by a "people-machine.” Gyung Kim, 6.

77 “Et qui veut trop gagner perd.” In Sircos and Pallier, 191.

${ }^{78}$ Princess Dashkova, Mon Histoire, (Paris: L’Harmattan, 1999), 187.
} 
Pugachev," Catherine's reading notes show that she was also irritated by Radishchev's ambition to draw undue attention upon himself. ${ }^{79}$ However different in intensity, Dashkova's and the Empress' reactions to Radishchev's behavior show a common condemnation of the attempt of an individual to act outside his official capacity, as Vorontsov's subordinate or member of Catherine's serving nobility, just as Miolan had been mocked for his ambition to transcend his sacerdotal status and pretend to the status of a physicist. As a satirical song went:

Cet abbé qui fit tant de bruit,

En ce jour perd tout son credit,

En sortant de sa sphère.

This abbot, who made so much noise,

In one day lost all his credit,

By leaving his sphere. ${ }^{80}$

Radishchev's punishment, however, was of a different nature than that imposed upon Miolan. First condemned to death, he was eventually exiled in Siberia. Miolan, on the contrary, suffered an exclusion, imposed upon him not by the State, but by the public sphere. Strikingly, however, in order to name Miolan's fate, Karamzin chose a term which could be applied to Radishchev. In "Letters of a Russian Traveler," the exclusion of the unsuccessful abbot by the public in Paris is referred to as a "citizen's death" ("grazhdanskaia smert"), a term used in some Russian eighteenth-century law texts as a loose equivalent to the concept of "political death" ("politicheskaia smert"), which, once it had been deprived of its original most brutal ritual aspects (a knout beating and the ripping apart of the convict's nostrils), essentially designated the deprivation of a subject's rights and his deportation, most of the time to Siberia. ${ }^{81}$ The use of this term, known in Russia for its tragic meaning, to depict a much lighter fate in France, testifies of Karamzin's intent to draw the attention of his readers' on a significant difference between the two countries.

This significant difference is what triggered Karamzin's interest in the second anecdote on Miolan, taken from Mirabeau's letters, and explains why Karamzin combined the two anecdotes on the two unfortunate Abbotts, the real Miolan and the fake one. Citing the concept of "citizen's death" in his first anecdote in order to stress its meaning in France, Karamzin exemplifies it by showing it in action in the second. The tall Abbot is excluded from the theatre, a microcosm for French society in general, ${ }^{82}$ just as Miolan had been

\footnotetext{
${ }^{79}$ D. S. Babkin, Protsess Radishcheva, (Moscow-Leningrad: Izd. Akademii nauk SSSR, 1952), 157, 160.

${ }^{80}$ Sircos and Pallier, 190. Additional epigrams from satirical prints and songs of the time conveyed a similar message, for instance "Chacun son métier, les vaches seront bien gardées" ("May people stick to their own job, and cows will be kept safe").

${ }^{81}$ On “citizen's death" ("grazhdanskaia smert") and political death ("politicheskaia smert”), as well as on their relation to the concept of "shel'movanie" and the practice of exile in eightenth-century Russia, see E. Marasinova, "Zakon" $i$ "grazhdanin" $v$ Rossii vtoroi poloviny XVIII veka: ocherki istorii obshchestvennogo soznaniia (Moscow: NLO, 2017), 73-112, notably 111.

${ }^{82}$ Theater-going is at the center of both Fonvizin's and Karamzin's narratives about travel to France. Obviously, both writers understood that it was a privileged place to watch the spectacle of French society and politics. On theater and politics in revolutionary Paris, see P. Friedland, Political Actors: Representative Bodies $\mathcal{E}$ Theatricality in the Age of the French Revolution (Ithaca: Cornell University Press,
} 
from Parisian society by songs and caricatures. This sentence, however, is pronounced by a different actor than the enraged mob from the Luxembourg Garden, similar to the one Karamzin had seen in Strasbourg and whose violence he had condemned. It is pronounced by the smart lawyer at the theater, whose wit the Russian writer admires, as Mirabeau had in his letter to Chamfort, and who represents the countless anonymous authors of satirical songs, caricatures and bons mots, as well as the people who consume them, notably from the polite society.

Social regulation, in Karamzin's conception, should therefore obviously be enforced by the public sphere, not by an enraged mob, nor by a violent state. By telling Miolan's story and describing the regulation of individual folly by the enlightened public, Karamzin exposed his ideal conception of social order, in which his and the nobility's aspirations for cultural and social autonomy, if reasonable, that is self-regulated, should be tolerated by a benevolent monarchy ${ }^{83}$ and if not, should not be brutally punished, as in Radishchev's case, but regulated by the enlightened public. ${ }^{84}$

\section{Conclusion}

This study of Karamzin's use of the anecdote on Abbé Miolan's aborted flight shows that, because of the Russian writer's indifference to science and the pace of change in spectacular science in the eighteenth century, what could have been a narrative about foreign technology and a case of technology transfer through literature, turned into a reflection on social order and political management. Considering that hot air balloons had initially triggered numerous reveries on liberty and equality, ${ }^{85}$ it may seem strange at first to see an anecdote about aerostation used as a narrative about disciplining. This conservative view of aerostation, however, was, in Karamzin's "Letters of a Russian Traveler," the very condition for the promotion of the writer's aspirations to social and cultural autonomy, which bore the seeds of a reasonable form of political modernity.

\footnotetext{
2002). On the importance of the theater as a political place in Karamzin's "Letters of a Russian Traveler," see Iu. Lotman, Sotvorenie Karamzina, (St. Petersburg: Isskustvo-SPb., 1997), 134-46; Baudin, 2011, 147-55. ${ }^{83}$ On Karamzin's conception of the monarchy and his insistence on the importance of civil and intellectual rights over political ones, see R. Pipes, "Karamzin's conception of the monarchy," in Black, 105-26. For a similar opinion, see Lotman, 192.

${ }^{84} \mathrm{On}$ an alternative depiction of the functioning of the public sphere as the embodiment of a harmonious social order, see K. Kobrin, "Karamzin v Leiptsige: estestvennyi evropeiskii poriadok veshchei," Neprikosnovennyi zapas, 2 (2017): 98-110.

${ }^{85}$ Gillespie, 264; R. Darnton also quotes an episode from a flight organized in Lyon on January 19, 1784, during which a young commoner told some aristocrats, who were trying to prevent him from boarding with them on the balloon: "Sur terre je vous respectois, mais ici nous sommes égaux" ("On the ground I owed you respect, but here we're all equal”). This episode was largely publicized, notably in the Journal de Bruxelles. See R. Darnton, La fin des Lumières. Le mesmérisme et la Révolution, (Paris: Perrin, 1984), 176.
} 